\title{
Challenges of Sustainability in Radio Broadcasting Towards a Media Convergence Era by Marketing Public Relations Activities to Create Awareness of Prambors Radio in Indonesia
}

\author{
Eka Wulan Sari \\ Communication Department \\ Bina Nusantara University \\ Jakarta, Indonesia \\ ekawulandrea@gmail.com \\ Johana Brigitha Mone \\ Communication Department \\ Bina Nusantara University \\ Jakarta, Indonesia \\ johanamone@gmail.com
}

\author{
Rahmat Edi Irawan \\ Communication Department \\ Bina Nusantara University \\ Jakarta, Indonesia \\ reirawan@yahoo.co.id \\ Muhamad Aras \\ Communication Department \\ Bina Nusantara University \\ Jakarta, Indonesia \\ maras@binus.edu
}

\begin{abstract}
This research aims to examine the challenges of sustainability in radio broadcasting of Prambors radio toward media convergence by marketing communication activities to create awareness. The research uses a case study method. The data was obtained through open interviews, non-participant observations, and public documentation such as the company profile, the company website, and social media. The data analysis used a coding concept consisting of open coding, axial coding, and selective coding. The research results indicate that Prambors radio realized that to be able to endure in this media convergence era nowadays, it needs marketing communications activities like events and publications, sponsorships, speeches, news creations, community service, and media identity to create awareness to stay in the public's mind and always listen. These are also marketing communication activities by Prambors radio to make it stay in the public's mind to be a top hits music station.
\end{abstract}

Keywords: Digital Technology, Media Convergence, Radio, Marketing Communications, Brand Awareness, Image

\section{INTRODUCTION}

The phenomenon of the Internet growth has resulted in the rapid expansion of online content. The Internet is particularly more attractive than traditional means. For media, convergence is a window to gain an opportunity for traditional media to align itself with new technology. Technological capabilities are key to enabling the daily process of convergence to occur as well as understanding the users and what their content delivery needs might be. The Internet and computer users have raised the bar for content providers on what is expected from an online experience. The Internet has become a channel for media companies to reach a younger audience while trying to maintain the existing audiences. The integration of content across media platforms to connect with users is part of the goal of convergence in media organizations. Point convergence is the blending of old media or traditional media, such as magazines, television, newspapers, and radio with new media like computers and the Internet [1]. Since the first radio discovered web streaming in the 1990s, it can be assumed that a radio station should be broadcasted simultaneously online. The rise of smartphones during the first part of the century meant that radio stations also felt compelled to have an application to allow the audience to listen via a mobile phone. The Internet is more than just a platform through which to push audio streams. When the radio first appeared on the Web, listeners and the public agreed that the Internet gave broadcasters fresh opportunities to prepare good content. The coming of $3 \mathrm{G}$ and 4G mobile Internet connections allows listeners to consume radio online on mobile devices. The Internet not only offers radio programs an opportunity to interact directly with audiences, it also allows broadcasters to offer graphics, videos, and images [2]. There is a noticeable move towards the visualization of radio programming through more of a process of live HD cameras, recorded events, and enhanced radio experiences. We can recognize that contemporary radio listening can be done via devices with screens such as digital televisions by connected radio sets, smartphones, or laptops. Since the mid-2000, radio programs have been experimenting with visualized radio where listeners can see programs as well as hear them. The national BBC radio networks for young people are radio I and radio I xtra. The two services recently moved to new studios at a new broadcasting house in central London, designed with the desire to visualize more. Besides radio studios and production spaces, there are also cameras, lighting rooms, and control rooms to allow the content to be shot, edited, and streamed live online with ease [2]. Today, radio is being consumed in new and different ways across a variety of platforms and devices, yet the traditional strengths of radio are undiminished: mobility, ease of access, real-time broadcasting, integration with the community, personalities, entertainment, established journalistic standards, and creative audio programming. The challenge is to transpose these strengths and unique attributes into a new media environment. Meanwhile, the threat to radio 
is that other media and new devices could potentially become substitutes for it in some of these areas. The threat may not be immediate [2].

Based on a survey that was taken from the company profile of Prambors radio, today the radio is still in first place for the young generation to find new music hits with the radio having $62 \%$, YouTube channel having 18\%, and online streaming having $10 \%$. To listen to one's favorite music, the radio still takes first place with $60 \%$, online streaming $18 \%$, and Spotify $10 \%$. The medium to listen to the radio now is dominated by the cellular phone with $52 \%$, digital streaming $19 \%$, and the car radio $15 \%$ [3].

Basically, finding the right model in media convergence is not easy. The media in Indonesia now is in the process of finding the right convergence model and new culture. Media convergence encourages broadcasters to be more creative and adaptable. Prambors radio is a CHR (contemporary hit radio station) with the "Indonesian \#1 hits music station" as the tagline. Prambors radio plays $80 \%$ international music and $20 \%$ local music and continues to be young stars favorite radio since 1971 with $\mathrm{A} \mathrm{B}+$ social economic classes with 52\% college students, $27 \%$ first time workers, and $18 \%$ high school students. Prambors radio calls their listeners as "Kawula Muda" with the target market age range of 15-29 years old and core listeners 18-24 years old. The profile from the Parambors' listeners who are also known as millennials are active in their community and have become opinion leaders among their peers. The brand of Prambors radio listeners are fun, up-to-date, hip, creative, social media savvy, and appreciative of art and culture. Now, Prambors radio has a network dispersed in 9 big cities in Indonesia: Bandung, Solo, Surabaya, Jakarta, Semarang, Makassar, Medan, Jogjakarta, and Manado [4]. When we talk about radio, it cannot be separated with broadcasting. It is explained that "Broadcasting is an activity of transmitting broadcasts through a means of transmission and or means of transmission on land, at sea, or in space by using the radio frequency spectrum by air, cable, and/or other media to be received simultaneously by a community with broadcast receiving devices." The radio is a medium of mass communication with the ability to reach a wide audience at the same time. With that capability, the radio certainly has great potential in conveying and disseminating information. Therefore, the radio can broadcast quickly and directly. As part of the media mass, the radio has properties that can be advantageous in conveying messages to the community. Regarding the beneficial characteristics, the radio is cheap, has unlimited transmission time, has sound, has music, does not require focused attention, and can be a faithful friend in doing one's daily life activities [5].

Media theorist Henry Jenkins [6] argues that convergence is not the result but a process that changes how media is produced and consumed, as follows:

A. Economic convergence occurs when a company controls several products or services in the same industry.

B. Social or organic convergence occurs when someone watches various types of television programs or television broadcasts online and at the same time conducts online communication in the form of exchanging text messages with friends while also listening to music.

C. Technology convergence is the integration of various technologies, namely when one or more different media is transformed into a digital form.

D. Cultural convergence occurs when various stories flow to various forms of media that are one component.

E. Global convergence is a process of cultural influence that is geographically distant to other cultures.

As a form of mass media, the radio cannot avoid the media convergence that occurs but instead must consider media convergence with various platforms as a challenge that must be answered to survive in this digital era. Nowadays, Prambors radio has a digital asset to support the on-air format, with the digital media assets of Prambors radio optimistic that the radio can still survive in this convergence era. For the digital asset, Prambors radio has a website (www.pramborsfm.com). The Prambors website provides streaming radio, news, and top 40 charts which are one of the music chart references in Indonesia. The Prambors website is the number one youth radio station website in Indonesia, according to www.alexa.com. The Prambors radio application is available on Android and Apple Store with streaming of more than 4 million per month and unique users of more than 800,000 per month. For the social asset, Prambors radio has Instagram with 300,000 followers. Prambors radio Instagram is the most followed radio station on Instagram in Indonesia. Its Facebook page has more than 500,000 friends, Twitter has more than 2.5 million followers, and YouTube has 50,000 subscribers [4] Compared to the other radio competitors, Prambors radio is still the number one radio station with the best digital media marketing activities [4]

Talking about radio, it does not come as a surprise talking about the business side as one of the keys to survive. In the radio business, professionals, advertisers, and listeners are their real customers, because in the media business selling listeners to advertisers and persuading advertisers to buy airtime on a radio station depends on the research results of listeners and how many listeners they have.

The research which is conducted in media is called a rating, which provides an estimated number of how many people listen to a radio station at a certain time. The rating also divides the listeners based on demographics which are of course very important for advertisers. They can know the target of the advertisement that will be put on a radio station, whether it is young people, parents, men, or women. Straubhaar concluded that a rating is a measurement of how many people who listen to a radio station. From the rating also, we can know which radio stations stay in the public's minds. Naturally, humans will prefer to choose something that is familiar in their minds and the people around them [7]. The task is how to keep the brand alive. A brand itself can be defined as a name, term, sign, symbol, or design combination of them, intended to identify the goods or services of one seller and differentiate them from those of the competitors" [8] . Brands are names, terms, symbols, or special designs or 
some combination of elements designed to identify goods or services offered by the seller. Brands are a seller's promise to consistently provide certain features, benefits, and services to buyers. The best brands provide quality assurance, but brands are more than symbols. Furthermore, the brand is actually a tangible and intangible aspect that is represented in a trademark that can create its own value and influence in the market if managed properly [9]. According to William J. Stanton [9], brands can have six levels of: attributes, brands provide an overview of the nature of the model itself and improve on certain attributes; benefits, attributes of a brand can be translated in the form of benefits both in terms of function and emotion; value, a brand can participate in providing better value to its producers; culture, a brand can participate in reflecting a particular culture; personal (personality), a brand can reflect the personality of the individual wearer; and user, brands indicate the type of consumer who buys or uses the product.

By the brand definitions stated above, it can be concluded that brands are names, complex symbols such as logos, trademarks, and packaging designs that are made to differentiate a product or service from other products or services. The product only describes the physical attributes and dimensions, so that there is no more than a commodity that can be exchanged. The brand can explain emotions and relationships with customers. This can happen because the brand contains values that are intangible, emotional, beliefs, hopes, and with customer perceptions based on it. With a good brand we also can have a good image too. An image is the set of beliefs, ideas, and impressions a person holds regarding an object. For the company, an image is the public perception of the identity. This perception is created based on the information it will have an effect of the size of consumers' buying interest to the products or services produced by the company. Consumers often buy products with well-known brands because they feel more comfortable with things that are already known, the assumption that famous brands are more reliable, always available, and easily searchable, and have undoubted quality, so that brands are better known and more often consumers choose them rather than brands that do not. [10]. Costumer-based equity acuurs when the consumer is aware and familiar with the brand and hold positive association about the brand in the memory. That is, there are to distinct types of brand knowledge: Brand Awareness and image [11] are brands forever. The more familiar or having a strong brand awareness a target audience is with a brand and the more positive, unique, and associated with the brand, the more the target audience will buy it [12] Prambors radio can sustain itself for more than 40 years as a top of mind youngster radio station in Indonesia, so that it must be helped with a strong brand awareness in their target listeners and the public. For this research, it is assumed that marketing public relations activities are needed to help. The important role of marketing a public relations strategy also integrates the functions of advertising, sales promotions, and marketing of the public relations themselves, because each needs to strengthen and harmonize each other [13] . Marketing public relations, according to Thomas L. Harris [14], is a process from planning, implementing, to evaluating programs that encourage buying interest and customer satisfaction through the delivery of information and convincing impressions to show that companies and products are in accordance with the needs, desires, and interests of consumers. In general, [15] marketing public relations can be interpreted as a process of planning, implementing, and evaluating programs that can affect customer purchases and satisfaction through communication. This can be done through information that can be trusted as well as positive impressions related to the identity of the company or its products according to the needs, desires, and interests of its customers. Based on this understanding, it can be concluded that marketing public relations is a combination of program implementation and marketing strategies with work program activities for public relations from planning, implementation, to evaluation. A successful measuring instrument for marketing a public relations strategy is if you successfully integrate or utilize the big name of the corporation to support the success of a product.

To carry out the marketing public relations strategy effectively, it is necessary to choose the right marketing public relations tool. There are seven main tools of marketing public relations [10], which are:

A. Publications and publicity. Every function and task of marketing public relations is to carry out publications or disseminate information through various corporate media regarding companies or organizations that are appropriate for the public to know. The purpose of this publication is so that people know the existence of a brand from the organization. In addition, public relations also generate publicity to get a wider positive response from the public.

B. Event (program preparation program). Marketing public relations also designs certain events that are selected within a certain period, place, and object specifically to influence the public. Through corporate events, it can attract the public's attention to the company's brand.

C. Sponsorship. The company can give sponsorship to certain events. This is part of the company's promotional activities of brand names. The sponsored program will help a brand to be more quickly recognized by event visitors.

D. News (creating news). One of the main jobs of public relations is to create or find an activity that suits the company, its products, people, or employees, and also makes the media interested in making press releases and coming to the press conference managed by the company.

E. Speech. It is an activity carried out by a company to convey ideas or as an activity to convey information to audiences with the aim of building images. Usually company executives have to face every question and answer them.

F. Community service activities. These are the activities carried out to gain public sympathy. Community service activities can be useful to attract attention, so that it is expected to get a response in the form of a positive image. Companies can build good faith by donating money and time to charity activities.

G. Media corporate identity. Companies need a visual identity that is immediately recognized by the public. Media identity can be in the form of company 
attributes or brands in a visual form that can be directly seen by the audience, such as company logos, stationery, brochures, signs, business forms, buildings, uniforms, and how to dress.

Based on the explanation above, it can be said that the seven main tools of marketing public relations can be used as a tool for a communication strategy to build strong awareness continuously.

\section{RESEARCH METHODS}

This study provides challenges of sustainability in radio broadcasting towards media convergence) by marketing public relations activities to create awareness of Prambors radio. Therefore, this research uses a qualitative method, where researchers explore and understand the meaning of each individual or group of people related to the problem or phenomenon under study [16] The research design used is a case study. A case study design explores real life, collects data in detail and in-depth by involving several sources of information, as well as reporting research results descriptively [17]. Case study research provides a deep understanding of the object under study. Therefore, one data source is not enough. To develop a deep understanding of the object under study, researchers collect various forms of qualitative data through interviews and observations [17]

In the data collection process, open interviews were conducted with several informants, so that understandings of the views, attitudes, feelings, and behaviors of individuals or groups of people were obtained [17]. The data analysis technique used in this study consisted of open coding, axial coding, and selective coding [17]. Furthermore, for the data validity, the researchers used source triangulation by conducting an interview with the content director and also taking care of the Prambors radio branding strategy as informant A. There are six sources of evidence that can be used as a focus for the data collection of case studies, such as documents, records, archives, interviews, direct observations, the observations of actors, and physical devices [18].

The triangulation is a technique for checking the validity of the data by using something outside the data that has been obtained from the study as a comparison [19] .That way, researchers can compare the reality of the research with the formulation and planning that had been made by Prambors radio.

\section{RESULT}

Prambors radio used technology to present new media and "came out" from the conventional radio concept and created a new radio format form which is a convergence between the website and the social media network. The listeners can access both types of media or can choose one media only to be able to listen to this radio broadcast activity. Related with the youthful spirit of the listeners, Prambors radio is always open with the changes that happen and even make it a trend. The product image, which is a set of associations perceived by consumers about a product, includes the product attributes, benefits for consumers and users, and guarantees. What makes a brand sustainable and long lasting is the awareness and image, which are the main determinants of a brand's longterm success [17] Both are keys to the persuasion power of strong brands. Besides that awareness is the necessary condition to ensure that a brand plays a role to sustain itself [20] Other paragraphs are indented (BodytextIndented style).

Based on the results of the interview, nowadays, the radio is still considered as a conventional media that is far behind compared to current television programs, as well as print media with interesting content and layouts, especially with popular online media. Basically, since its inception, the radio has become a powerful mass communication media. In fact, the radio has been referred to as the fifth estate after newspapers. However, in line with technological developments, radio has also experienced several changes. The history of the radio shows that the development of the radio is also inseparable from technological developments that not only affect radio operations, but also the market, to redefine the radio itself in terms of its function and role. Along with technological developments, conventional media is transformed into convergence media. The radio is focused on information that can only be heard, how the delivery of information in both forms of entertainment must be understood by listeners. That makes the process more difficult compared to other media. A radio system must also be able to build the imagination of listeners to be able to receive information. The radio now has a challenge to compete with other mass media. As time goes by, the radio cannot be separated from the influence of globalization which always changes from time to time. Society is the main factor in its development that determines the life of a radio broadcast. The need for information and entertainment are two basic human traits that will determine whether the radio still attracts the public's attention. The community will tend to look for media that is better and more attractive in accordance with its needs.

The development of the Internet has become a new challenge for the radio. Nowadays, people are more interested in using the Internet than listening to broadcast radio. The community chooses media that can cover everything in both audio and audio visual formats. So, we often find that people prefer watching television or accessing the Internet rather than listening to the radio. In short, the radio is now being abandoned by some people.

In addition, another challenge comes from the production of radio programs. Urgent circumstances make most radios no longer idealistic and people prefer radio programs that can generate benefits for survival. Therefore, many radio programs are not educational, dependent, and uncritical. This will affect the reduction of loyal radio listeners. Another challenge is with the development of the Internet that is progressing. Anything can be accessed via the Internet. The radio is a mass media which also presents sound, including songs. In the past, when the radio was still a medium that was very popular with the public, songs were released by radio stations for exclusivity. However, with the internet, songs can be downloaded freely anywhere, anytime and music can be listening with many platforms. Furthermore, there are many radio stations now copying larger and more successful radio programs. This shows a lack of creativity in shaping the program. When the plagiarized program was implemented, it was not as successful as the radio that had used the program before. This is also a waste of time and disadvantageous. The difficulty in getting good and quality human resources is also another challenge faced by radio stations today. Many quality human resources make radio a stepping stone to be able to continue to a higher level. Cost problems also sometimes 
become a challenge for radio stations. Many radio stations has good programs. However, because there is no cost to produce it, the program is not realized. Competition with other radio stations, especially with online radio stations, is mushrooming today. Anyone can make radio broadcasts at an affordable cost. Like streaming radio, online radio is also mushrooming. Furthermore, it is difficult to get advertisements for radio stations. Many advertisers are more interested in advertising on television than on radio.

Seeing the many challenges of the radio today, there needs to be a strategy to be able to continue to maintain the existence of the radio as a mass media and public communication media. In this case, as a communication medium that relies on sound (sound), new innovations are needed which can attract the public's attention to continue listening to the radio. By building interesting programs that are not yet on other radio stations, it will create competition with other radio stations.

Programs or content created are tailored to the development of trends that are popular with most people. In addition, it increases the two-way communication to make the radio more interactive, by creating interactive broadcasts that are not just questions and answers, vents, and song requests. Create an interactive program that educates the public and is packaged attractively. Also, bring speakers who are able to make the atmosphere of the broadcast more interactive and fun to listen to.

In addition, a strong brand in a media company is also needed. The radio company must be able to attract advertisements so that it can continue to survive. It also relates to good radio programs. Continuous branding and attractive packaging are also required, so that people know and are interested in listening to the radio. Following the times, online radio can also be a good alternative to present radio programs so the conventional radio is a must to change if it does not want to be outdated. The strategy that needs to be done also comes from internal factors, as in how commitment and good teamwork can make radio programs greatly affect radio performance and quality. Therefore, there is a need for quality, commitment, and strong cooperation to be able to continue to contribute to provide information and entertainment for the community.

Related to how to manage the radio in the future, it will be a bigger challenge for the radio industry in Indonesia. There is a need for creative innovation. It is undeniable that money is one of the main determinants of radio in the future. In other words, managing the radio requires a fee. Radio companies must be able to convince advertisers and capital owners to keep the radio afloat.

In addition, the radio in the future can provide idealistic information with quality information, educate, provide insight and knowledge, and offer good entertainment facilities. Coupled with quality human resources and capable of being committed, it also makes the radio a platform for a means of accommodating good aspirations and discussions. The radio can also be a means or container that accommodates the creativity of the younger generation. The radio can be used to present Indonesian art and cultural information.

Departing from this reality, this research attempts to see how Prambors radio can sustain itself in the media convergence era by marketing the public relations roles of Prambors Radio, such as events and publications, sponsorships, news creations or campaigns, speeches, community service activities, and media corporate identity. The results of this research are as follows:

\section{A. Events and Publications}

In the terms of events, Prambors radio regularly holds events to engage the listeners. Prambors radio divides the events to be formatted on air, online, and on ground. Here are some events that are held by Prambors radio: Konser Bintang Jatuh; it is an event to invite the luckiest listeners to watch world musician concerts overseas. Wadyabala hunt is an event to search for future announcers in Prambors radio. Kabur Libur is an event to choose the lucky listeners to get a free holiday trip with a favorite announcer. Fifa World Cup is a radio event that will give free tickets to watch the World Cup in Russia (2018). Kumpul Kamu is a mini workshop with the trending topics that are happening now in Kawula Muda. If you would like to participate, just register your bio through the Prambors radio website. Skulprize is an activity to prove your school is the coolest. Prambors radio will come to your school and bring a popular artist. Mangkal bareng Prambors will invite you to come to join this event to watch an Indonesian music artist concert at Pekan Raya Jakarta. Ngedate bareng Wadyabala will treat you with Kawula Muda and you will get one day of fun together with a Prambors' announcer, lunch, shopping, until dinner. Cash truck is a car that goes around and brings cash. Kawula Muda must search for that car and get the money from them, get the clue of where the car is only from Prambors radio. The main purposes of holding an event are to get awareness, improve the knowledge of the community towards the company, obtain a positive publication through a reciprocal atomic interface, demonstrate good intentions between Prambors radio and their listeners, and also provide positive feedback for the public as its target public and attract creativity. Besides that, other reasons why Prambors radio regularly holds an event are to provide information directly (face-to-face), get positive feedback from the target audience, become a communication media, and get publicity. Related with publicity, Prambors radio as a mass media also does publicity activities. This keeps Prambors radio in the public's and target audience's minds. Sending releases, having media gatherings, and establishing relations are regular activities done by Prambors radio to maintain relationships with other media and get coverage. Some of the goals of Prambors radio in doing promotional activities are to inform, influence, persuade, and remind the target audience about the company or its activities.

\section{B. Sponsorship}

In terms of sponsorship, Prambors radio also supports various other events that are related with their target listeners. Being a media partner is one of the sponsorship activities that are usually did by Prambors radio. The events chosen are based on the similarities of the target public and the Prambors radio target listeners. Being a media partner in one event for Prambors radio has many benefits to raise awareness. The most important is to make good relationships with other industries that related, from give sponsorship such as "Promoin Pensi" (pentas seni) and Sekolah Kamu, Prambors radio can give a master of ceremony (MC) for your pensi. 


\section{Creating News (campaign)}

In terms of news, together with other stations that join in PRRSNI, Prambors radio makes big news value to make the public remember again about the radio. PRSSNI members made one big campaign in April 2017 to stop radio broadcasts for 15 minutes in all radio broadcasts. After fifteen minutes, the President said some words "Emang enak ga ada radio?" which was continued with the national song Indonesia Raya. This campaign had a high impact including coverage by the media. Creating news is one of the important elements to be remembered. Besides that, with the breakthrough events that are held by Prambors radio, it also has the purpose to get media coverage.

\section{Speech}

Announcers have an important role in the radio broadcasting business. Sometimes announcers are the representative image of the radio station, wherever they are. Announcers make the radio livelier and have a big part in the story of it. As a part of the convergence, now listeners can know and keep in touch with their favorite announcers by social media, the Web, and even chat to keep their image. Radio stations even take care of their personal social media, Web, etc. Prambors radio always involves the announcers as brand ambassadors that represent Prambors radio's image in every event and campaign. The Prambors' announcers are its profile.

\section{E. Community service activities}

Parts of community service activities, Prambors radio give slots for public service announcements (PSA). Public service announcements are one of the corporate social responsibilities (CSR) that Prambors radio usually does to support the government and non-profit organizations without any payments by giving free slots to promote the CSR programs in Prambors radio. For example,Prambors radio give slot to announce how to give charity for Palu earthquake victims, CSR can show that the company cares about others, give a good corporate image to the company in terms of public opinion.

\section{F. Media Corporate Identity}

One of the elements of corporate identity that makes the public aware of an institution is a t tagline and logo because both are the first things that people will know about an institution. Prambors radio has "si jabrik" as the logo. The Prambors logo also has a meaning, namely "The Spiky" who has curly hair that presents ongoing Prambors' activities and unlimited growth. The eyes show sharpness, focus, optimism, and forward thinking. The dark circle presents a community of young urban Indonesians who are active and have global knowledge. The black Prambors writing shows the presentation of music, programs, and information to listeners. The yellow background of the symbolization of Prambors is young and creative. The tagline "Prambors, Indonesia's \#1 hits music station" describes that Prambors radio is the one place you can count on to find whatever hit songs, updated news, and information for "Kawula Muda"

\section{CONCLUSION}

Based on the research results, it can be concluded that the challenges of sustainability in radio broadcasting towards media convergence by a marketing public relations strategy to create awareness starts with the introduction of the phenomenon of media convergence, so that media struggling with the developing technology keeps being sustainable, implements a strategy, observes listeners' habits in this convergence era and contributes to branding awareness in the public's mind as a strength to stay in the public's minds. In relation with the existing concept challenges of sustainability of radio broadcasting towards media convergence by marketing a public relations strategy to create awareness in Prambors radio, this is in line with the main tools of marketing public relations that consist of publications and publicity, events, sponsorships, news (creating news), speeches, community service activities, and media corporate identity. The challenges of sustainability in radio broadcasting towards media convergence by marketing a public relations strategy are successfully overcome to create awareness in the public's minds.

\section{REFERENCES}

[1] P. B. a. A. F. T. Langner, "Managing brands in a converging media environment," in Media and Convergence Management,," pp. 135-160, 2013.

[2] G. Lawson - Borders, " "Integrating new media and old media: Seven observations of convergence as a strategy for best practices in media organizations,," Int. J. Media Manag, 2003.

[3] G. S. a. G. S. M. Oliveira, "Radio: The Resilient Medium," 2014.

[4] Prambors, "Company Profile Prambors Radio 2018," Prambors radio, Jakarta, 2018

[5] F. Jefkins, "Periklanan.," Erlangga, Jakarta, 1996.

[6] F. Jefkins, Convergence Culture: Where Old and New Media Collide, London: New York University Press, 2016.

[7] R. L. a. L. D. J. Straaubhar, Media Now: Understanding Media, Culture, and Technology, USA: Cengage Learning, 2014.

[8] K. L. Keller, Strategic Brand Management, England: Pearson Education Ltd, 2013.

[9] W. J. Stanton, Prinsip Pemasaran. Indonesia:, indonesia: Gelora Aksara Pratama, 1996.

[10] D. A. a. A. L. Biel, Advertising and Consumer Psychology - Brand Equity \& Advertising: Advertising's Role in Building Strong Brand., London: Lawrence Erlbaum Associate Inc, 1993.

[11] T. L. B. H. S. a. P. G. P. F. R. Esch, "“Are Brands Forever? How Brand Knowledge and Relationships Affect Current and Future Purchases," Journal of Product \& Brand Management., vol. 15(20), pp. 98-105, 2006.

[12] H. Alifahmi, Marketing Communications Orchestra: Harmonisasi Iklan, Promosi, dan Marketing Public Relation, Bandung: Examedia Publishing, 2008.

[13] S. S. S. P. R. R. 2. E. Ardianto, Dasar - Dasar Public Relation., Bandung: PT. Remaja Rosdakarya, 2010.

[14] R. R. Jakarta, Manajemen Public Relations dan Media Komunikasi., Jakarta: Rajawali Pers, 2010.

[15] R. D. J. P. P. 2. J.W. Creswell, Research Design, Jogyakarta: Pustaka Pelajar, 2016 .

[16] C. J.W, Penelitian kualitatif dan design riset, JoGJakarta: Pustaka Pelajar, 2014.

[17] M. P. K. B. P. R. R. 2. D. L. Moleong, Metodologi Penelitian Kualitatif, Bandung: Pt. Remaja ROSDA KARYA, 2016.

[18] Robert.K.Yin, Studi kasus design \& metode, Depok, 2002 .

[19] S. B. M. K. L. Keller, Strategic Brand Management., England: Pearson Education Limited, 2013. 
[20] G. Lawson - Borders, "Integrating new media and old media: Seven observations of convergence as a strategy for best practices in media organizations," Int. J. Media Manag, Vols. vol. 5, no. 2, p. pp. 91 - 99, 2003.

[21] J. Creswell, Research Design, Jogjakarta : Pustaka Pelajar, 2016.
[22] a. K. L. K. P. Kotler, Marketing Management. One Lake Street, Upper Saddle River,, New Jersey: Pearson Education, 2012.

[23] D. L. Moleong, Metodologi Penelitian Kualitatif, Bandung: PT. Remaja Rosdakarya, 2016. 